\title{
Islamic banks concern with the poor and micro businesses: an evaluation on their Al Qard Hasan (beautiful loan)
}

\author{
E. A. Firmansyah ${ }^{1, *}$ \\ ${ }^{1}$ Department of Management and Business, Faculty of Economics and Business, Universitas Padjadjaran, Indonesia \\ *Corresponding author: egi.firmansyah@unpad.ac.id
}

\section{ABSTRACT}

Islamic Banks came up with one of the notions as stated in the Quran (59:7) $)^{\mathrm{i}}$, wealth must not be a perpetual distribution among the rich. This can be manifested in the form of distributing credit to the real business sector through a financing product, namely $A l$ qard hasan (beautiful or benevolent loan). This paper is aimed at investigating the role or performance of Islamic banks in distributing $A l$ qard hasan, usually given to the micro businesses, poor and less bankable people. This research is a descriptive research employing financial data from banks' annual reports. The sample taken is Indonesia's four major sharia compliant banks (BUSN) which are also categorized as foreign exchange banks. The results show that over the period of observation, the Al qard hasan of all banks had a declining tendency. Among the four banks, BSM and BNIS are the banks which had the highest portion of Al qard hasan (over the total financing). This result evidenced that the government owned banks (BSM and BNIS) had more concern with the poor and micro businesses, compared to the privateowned banks (BMI and BMS). To the author's knowledge, this is the first study to address the issue of Al qard hasan in the Indonesian context using the major Islamic banks.

Keywords - alleviating poverty, Al qard hasan, Islamic Banks, micro businesses, poor people.

\section{INTRODUCTION}

Islamic banks are certainly different from the conventional banks. The major difference lies on the practice that Islamic banks do not charge or earn any interest because it is considered as riba (usury) and unlawful. In fact, riba is one of the major sins in Islam and so it must be highly avoided. Islamic banks do not finance the firms involving in forbidden activities such as selling alcohol, drugs, weapons, financial institution charging interest such as conventional banks and insurance companies. Another underlying principle is, Islamic banks are close to the real sectors. In Indonesia, these real sectors are mostly micro or small businesses as in any developing nations. This principle is applied in providing microfinance in the form of Al qard hasan (qard hasan) so the micro businesses are able to run the business. Nowadays, allowing the poor to have access to the financing is somewhat a central issue and termed as 'financial inclusion' (Hassan 2015). Evaluating the performance of qard hasan in major Islamic banks is important to evaluate banks' concern with the poor and micro businesses especially in developing country such as Indonesia.

Al qard hasan is benevolent loan or non-margin loan which was practiced since the era of the Prophet Muhammad (pbuh) and his companions. This loan is aimed at reducing poverty in the society (Osman 2016) and establishing socio-economic justice (Sayd et al. 2011). For aiming those noble goals, other instruments may also be practiced, i.e. alms (zakat and sadaqah) and a profit-loss share-based business model (Necati 2015). In addition, waqf has similarly important role in combating the poverty so the Islamic institutions involving in these activities can be integrated to finance the micro businesses and the poorest (Abdul Rahman \& Dean 2013). When they are financially empowered, the inequality among society shall be minimized.

Although alleviating poverty is not main the responsibility nor the primary goal of Islamic banks, Islamic banks are highly expected to give contribution in it since acting in poverty alleviation is one of the aspects that differs Islamic banks from their conventional counterparts, through a financial product such as qard hasan. The conventional banks have no products which charge no interest because this is deemed not profitable. Thus, by providing qard hasan, Islamic banks have 
shown their stance that they are responsible for empowering the poor and micro businesses.

Meanwhile the number of fund distributed by Indonesian Islamic banks to the micro businesses through the qard hasan might increase, the ratio of qard hasan to total financing needs to be studied to know whether it increased or decreased. This paper tries to contribute in it. In addition to that, this paper also identifies which bank(s) had the better performance in terms of distributing qard hasan over the year of observation, i.e. from 2010 to 2015 .

The remainder of the paper is organized as follows. The author first introduced the concept of qard hasan and research methodology. The selected publications regarding qard hasan and poverty alleviation are provided. Finally, the author outlined the main findings, discussed implications and suggested avenues for the forthcoming research.

\section{LITERATURE REVIEW}

\section{Al Qard Hasan}

The literal meaning of Al qard hasan is a beautiful loan and it is basically a loan or credit given by the lender without expectation to get return on the principal (Obaidullah 2015). This loan enables the fellow brethren to be financially assisted by the more fortunate Muslims (Saqib et al. 2015). This zero interest loan is highly helpful for those who are in financial hardship (Necati 2015). In fact, the Prophet Muhammad said that this loan has advantage over sadaqah as in the following hadith: "On the night on which I was taken on the Night Journey (Isra), I saw written at the gate of Paradise": "Charity brings a tenfold reward and a loan brings an eighteen fold reward". I said: "O Jibril! Why is a loan better than charity?" He said: 'Because the beggar asks when he has something, but the one who asks for loan does so only because he is in need" (Ibn Majah, Vol. 3, Book 15, Hadith 2,431). It is clear that every Muslim or every Islamic institution practicing Islamic values is very much recommended to provide loan aimed at helping others. This can be undertaken by providing qard hasan or benevolent loan commonly practiced in Islamic banks and any financial Islamic institution such as Baitul Maal wa Tamwil (BMT) (Kassim 2015, Adnan \& Ajija 2015). As financial intermediary, banks have a significant influence on wealth distribution, issues of poverty eradication and social justice (Kamla \& Rammal 2013).

\section{Practice of Al Qard Hasan}

The practice of qard hasan is now prevalent in Muslim countries such as Bangladesh (Hassan 1999), Pakistan (Saqib et al. 2015), Indonesia (Adnan \& Ajija 2015) or even in the country where Muslim is minority such as Australia (Ahmad \& Ahmad 2009). Todays, the qard hasan is also deemed as a manifestation of corporate social responsibility (CSR) because the main purpose of qard hasan and CSR is quite similar, that is helping poor people in society.

The practices of qard hasan in Indonesian banks are mostly in the form of pawning where the customers get loan by entrusting their goods as collateral. The Islamic banks are allowed to charge fees as the custodian or maintenance fees from this practice. It is assumed in this paper that the customers of pawning are the poor and micro businesses. It is a common practice for the poor and the small enterprises in developing nations to use pawning service from the banks to support their business operation or even to support their lives.

\section{Loan vs. Financing}

The regular loan in conventional banks cannot be applied in Islamic banks. In fact, as referring to the Quran, Islamic banks must give loan without any intention to get return or interest. In complying with this, Islamic banks offer a loan that is qard hasan. The product name of qard hasan varies among Islamic banks. However, by providing this kind of loan, Islamic banks may not get profit. For getting return, Islamic banks provide 'financing' such as car financing, home financing and business venture financing. As the financing is not the same as loan, gaining additional return for profit is allowed. The common financing contracts in Islamic banks are murabahah (selling in installment), musyarakah (partnership with capital sharing between bank and customer), mudharabah (partnership with bank as capital owner), ijarah (leasing), and istishna (manufacturing contract) (Saqib et al. 2015). In the financial reports of Islamic banks, qard hasan is located in balance sheet and it is categorized as account receivable of (qard funds).

\section{Al Qard Hasan and Poverty Alleviation}

Alleviating poverty is the main concern of human in today's era. This is also stated as the first priority to be tackled in the Sustainable Development Goals (SDGs) ${ }^{\text {ii }}$. In reducing the poverty, Islam has quite different 
approaches from the conventional approaches. Islam emphasizes more on the redistribution of wealth to improve the condition of the poor (Muhammad et al. 2015).

In redistributing the wealth, Islam teaches its followers to perform zakat, sadaqah, waqf, and qard hasan as practiced in Islamic Microfinance Institutions (MFI). All these financial instruments are important for ensuring fairness, equity, social peace, and for the completion of human basic needs so they are believed to reduce poverty. In the case of qard hasan, it is effective in reducing poverty as shown in some of previous researches (Widiyanto et al. 2011, Bhuiyan et al. 2012).

\section{METHOD}

This paper is a descriptive research using the sample of four major Islamic (sharia) banks in Indonesia. The sampling technique used here is purposive sampling. The data from four Islamic banks were collected specifically from their balance sheets in annual reports. Those banks as well as some of their data are shown in table 1.

\section{Table 1. Research Sample}

Those banks were taken as research sample due to the three following reasons; firstly they are among the first Islamic banks established in Indonesia, secondly they are categorized as the foreign exchange banks and one of them, i.e. BMI already has international branch in Kuala Lumpur, Malaysia, thirdly they published data needed for this research in their annual reports. Considering these reasons, the author believed that the four banks studied here are already settle so they have more capability to contribute to the poor or eradicate poverty by giving more portion in their zero interest loan, i.e. qard hasan.

This paper first describes the trend of qard hasan of each bank within the period of observation that is from 2010 until 2015 (six years). This period is chosen for the reason of data availability in the four banks taken as sample. To understand more on the tendency, the graph is also provided. Subsequently, this paper discusses ratio between the qard hasan of each bank to the total financing, i.e. murdharabah, musyarakah, istishna and ijarah to know some insightful information regarding their concern with the poor and small enterprises, whether increasing or decreasing over the observation period.

\section{RESULTS AND DISCUSSION}

Within the period of observation, the qard funds distributed by all banks vary with BSM had the highest potion in 2011 (around IDR 6.4 trillion) and BMS with the smallest portion in 2015 (around IDR 32 billion). In average, BSM distributed around IDR 4.3 trillion (the highest) while BMS around IDR 308 billion. In terms of average qard funds distributed to the borrowers, BSM is the highest, BMI is in the second position while BNIS and BMS are in the third and fourth position, respectively.

Over the period of six years, all banks were found to have decreasing tendency in their qard hasan distribution. For examples, BMI distributed around IDR 1.93 trillion in 2011 and only IDR 230 billion in 2015, BSM distributed around IDR 6.48 trillion in 2011 and only IDR 1.94 trillion in 2015, BMS distributed around IDR 603 billion in 2011 and only IDR 32 billion in 2015, and BNIS distributed around IDR 833 billion in 2011 and only IDR 559 billion in 2015. This decreasing tendency of qard hasan in all Islamic banks observed was caused by several factors, and one of the biggest factors is believed to be economy slowdown as happened in many other countries. It was understandable that Islamic banks took a prudent step by reducing the funds distributed to the debtors because the risk got higher during the slowdown or contracted economy. In fact, it would be even riskier if the credit given was not backed up by collateral, as in the case of qard hasan.

Within the six years, almost all of the banks had the highest portion of qard fund in 2011, except BMS in 2012. This implies that in the year 2011, almost all of banks in observation had a quite good performance. It also implies that in 2011, the economy condition was quite good, resulting in most of the banks providing more funds for the non-margin loan. However, this did not last long because subsequently, all banks had a decreasing trend in their qard hasan distribution.

For the total financing, BSM was in the first position with around IDR 35 trillion in average while BMI was in the second with averagely IDR 32 trillion. BNIS and BMS were in the third and fourth position with the total financing less than 10 trillion in average. Seeing these numbers, it can be implied that the big size bank such as BSM was more powerful to distribute more funds to the 
borrowers. In addition, the more experienced bank, i.e. BMI had more also more capability in distributing funds through its financial products such as saving product. In the other hands, BMS and BNIS which are considered newer and smaller had smaller portion of qard hasan and their total financing. The qard hasan and total financing of each bank are shown in table 2 .

Table 2. Qard hasan and total financing in four major Islamic banks from 2010-2015 (in Indonesian Rupiah)

To know the comparison of qard hasan to total financing of each bank, the ratio between these two numbers are shown in figure 1 . From figure 1 , it is shown that the ratio or the trend of qard hasan to total financing in all banks has a declining tendency (signed by descending line). From the year 2010 to 2015 all banks seemingly took an action to reduce the amount of funds distributed in qard hasan scheme. In fact, all banks took action to finance the businesses or consumers by using other contracts such as murabahah and musyarakah. With these two contracts, banks tried to secure their income because the nature of these contracts allow banks to minimize the risk by, for example, setting the collateral and using the scheme of selling. The declining trend of qard hasan may continue in 2016 if the economy got worse and if the banks performance in acquiring funds declines.

\section{Figure 1. Trend of the ratio of qard hasan to total financing}

\section{CONCLUDING REMARK}

The results of this research show that all Islamic banks observed within the period of 2010 to 2015, namely BSM, BMI, BMS and BNIS had a declining trend in their qard hasan distribution. In fact, the ratio of qard hasan to total financing also decreased. This shows that instead of offering qard hasan, all the Islamic banks prefer to offer more profitable products by using murabahah and musyarakah contract. This is understandable because within that period the economy was contracted, making the Islamic banks prioritize profitable products rather than 'social products' such as qard hasan.

From the evaluation conducted on the banks' qard hasan, it can be concluded that BSM had the best performance in terms of qard hasan distribution. BSM had the most concern by prioritizing its qard hasan to support the poor and micro businesses. From the result calculation, BSM had, in average, approximately $12.03 \%$ ratio of qard hasan to total financing, while in the second position is BNIS with $7.53 \%$. These two government-owned Islamic banks were better than the two other Islamic banks which are owned by private, i.e. $\mathrm{BMI}$ and BMS.

This research focuses on the description of qard hasan among Islamic banks by using descriptive statistic technique. The future researches are expected to be conducted by using a more advanced statistical tool in hope to find the determinants of qard hasan among Islamic banks. The future researches may investigate internal factors such as bank size, profit and revenue and external factors such as income per capita and inflation that may affect the qard hasan distribution of Islamic banks.

Conflict of interest: none declared.

\section{ACKNOWLEDGEMENT}

The author would like to thank to the head of business and management department (Professor Ernie) as well as the head of center of management and business studies (Dr. Imas) FEB Unpad for providing supports in writing this paper.

\section{REFERENCES}

Abdul Rahman, R. \& Dean, F., 2013. Challenges and solutions in Islamic microfinance. Humanomics, 29(4), pp.293-306. Available at: http://www.emeraldinsight.com/10.1108/H-062012-0013.

Adnan, M.A. \& Ajija, S.R., 2015. The Effectiveness of Baitul Maal Wat Tamwil in Reducing Poverty: The Case of Indonesian Islamic Microfinance Institution. Humanomics, 31(2), pp.160-182.

Ahmad, A.U.F. \& Ahmad, a. B.R., 2009. Islamic microfinance: the evidence from Australia. Humanomics, 25(3), pp.217-235.

Bhuiyan, A.B. et al., 2012. The Approaches of Islamic and Conventional Microfinancing for Poverty Alleviation and Sustainable Livelihood Institute for Environment and Development ( LESTARI ), School of Business and Technoprenuership , University Perlis Malaysia, Malaysia School of. American Journal of Applied Sciences, 9(9), pp.1385-1389. 
Hassan, A., 2015. Financial inclusion of the poor: from microcredit to Islamic microfinancial services. Humanomics, 31(3), pp.354-371.

Hassan, M.K., 1999. Islamic Banking in Theory and Practice: The Experience of Bangladesh. Managerial Finance, 25(5), pp.60-113.

Ibn Majah, Ibn, M.S., Vol. 3, Book 15, Hadith 2431, available at: http://sunnah.com/urn/1267490

Kamla, R. \& Rammal, H.G., 2013. Social reporting by Islamic banks: by does social justice matter? Accounting, Auditing \& Accountability Journa, 26(6), pp.911-945.

Kassim, P.W.S., 2016. Issues and challenges in financing the poor: case of baitul maal wa tamwil in Indonesia. International Journal of Bank Marketing, 34(2).

Muhammad, D. et al., 2015. International Journal of Islamic and Middle Eastern Finance and Management Article information:

Necati, A., 2015. International Journal of Islamic and Middle Eastern Finance and Management Article information: International Journal of Islamic and Middle Eastern Financial Management, 8(4), pp.491-507.

Obaidullah, M., 2015. Enhancing food security with Islamic microfinance: insights from some recent experiments. Agricultural Finance Review, 75(2), pp.142-168.

Osman, M.N.A.B.M., 2016. Islamic Social Business to Alleviate Poverty and Social Inequality. International Journal of Social Economics, 43(6).

Saqib, L. et al., 2015. Local agricultural financing and Islamic banks: is Qard-al-Hassan a possible solution? Journal of Small Business and Enterprise Development, 6(1), pp.122-147.

Sayd, F., Hassan, M.K. \& Roman, L., 2011. Determinants of corporate social responsibility disclosure: the case of Islamic banks. Journal of Islamic Accounting and Business Research, 2(2), pp.114-141.

Available at: http://dx.doi.org/10.1108/17590811111170539.

Widiyanto, W., Mutamimah, S. \& Hendar, H., 2011. Effectiveness of Qard al-hasan financing as a poverty alleviation model. Economic Journal of Emerging Markets, 3(1), pp.27-42. 
Table 1. Research Sample

\begin{tabular}{|c|c|c|c|}
\hline No & Bank & $\begin{array}{c}\text { Year of } \\
\text { Establishment }\end{array}$ & Status \\
\hline 1 & $\begin{array}{l}\text { Bank } \\
(\mathrm{BMI})\end{array}$ & 1991 & Private bank \\
\hline 2 & Bank Syariah Mandiri (BSM) & 1999 & Government-owned bank \\
\hline 3 & Bank Mega Syariah (BMS) & 2004 & Private bank \\
\hline 4 & Bank BNI Syariah (BNIS) & 2000 & Government-owned bank \\
\hline
\end{tabular}

Table 2. Qard hasan and total financing in four major Islamic banks from 2010-2015 (in Indonesian Rupiah)

\begin{tabular}{|c|c|c|c|c|c|c|c|c|}
\hline \multirow[b]{2}{*}{ Year } & \multicolumn{2}{|c|}{ BMI } & \multicolumn{2}{|c|}{ BSM } & \multicolumn{2}{|c|}{ BMS } & \multicolumn{2}{|c|}{ BNIS } \\
\hline & $\begin{array}{l}\text { Qard Hasan } \\
\text { financing }\end{array}$ & Total financing & $\begin{array}{l}\text { Qard Hasan } \\
\text { financing }\end{array}$ & Total financing & $\begin{array}{c}\text { Qard Hasan } \\
\text { financing }\end{array}$ & Total financing & $\begin{array}{l}\text { Qard Hasan } \\
\text { financing }\end{array}$ & Total financing \\
\hline 2010 & $1,183,738,000,000$ & $15,917,700,000,000$ & $2,235,862,035,491$ & $22,866,711,024,143$ & $66,370,252,000$ & $3,081,938,233,000$ & $211,767,000,000$ & $3,459,717,000,000$ \\
\hline 2011 & $1,933,610,000,000$ & $22,469,200,000,000$ & $6,487,865,313,730$ & $35,557,137,137,857$ & $603,876,559,000$ & $4,009,987,378,000$ & $833,261,000,000$ & $5,189,589,000,000$ \\
\hline 2012 & $1,275,670,000,000$ & $32,860,000,000,000$ & $6,133,646,853,577$ & $43,301,415,024,105$ & $810,310,771,000$ & $6,077,425,607,000$ & $734,290,000,000$ & $7,513,233,000,000$ \\
\hline 2013 & $420,636,000,000$ & $41,790,000,000,000$ & $5,554,738,792,079$ & $37,916,993,265,421$ & $261,676,122,000$ & $7,018,021,138,000$ & $627,739,000,000$ & $11,051,094,000,000$ \\
\hline 2014 & $127,454,600,000$ & $43,110,000,000,000$ & $3,585,399,805,295$ & $36,239,790,147,453$ & $77,214,930,000$ & $5,301,184,028,000$ & $638,347,000,000$ & $14,786,638,000,000$ \\
\hline 2015 & $230,577,482,000$ & $40,730,000,000,000$ & $1,931,683,810,194$ & $35,375,254,543,945$ & $32,473,141,000$ & $4,099,578,315,000$ & $559,206,000,000$ & $17,383,988,000,000$ \\
\hline
\end{tabular}




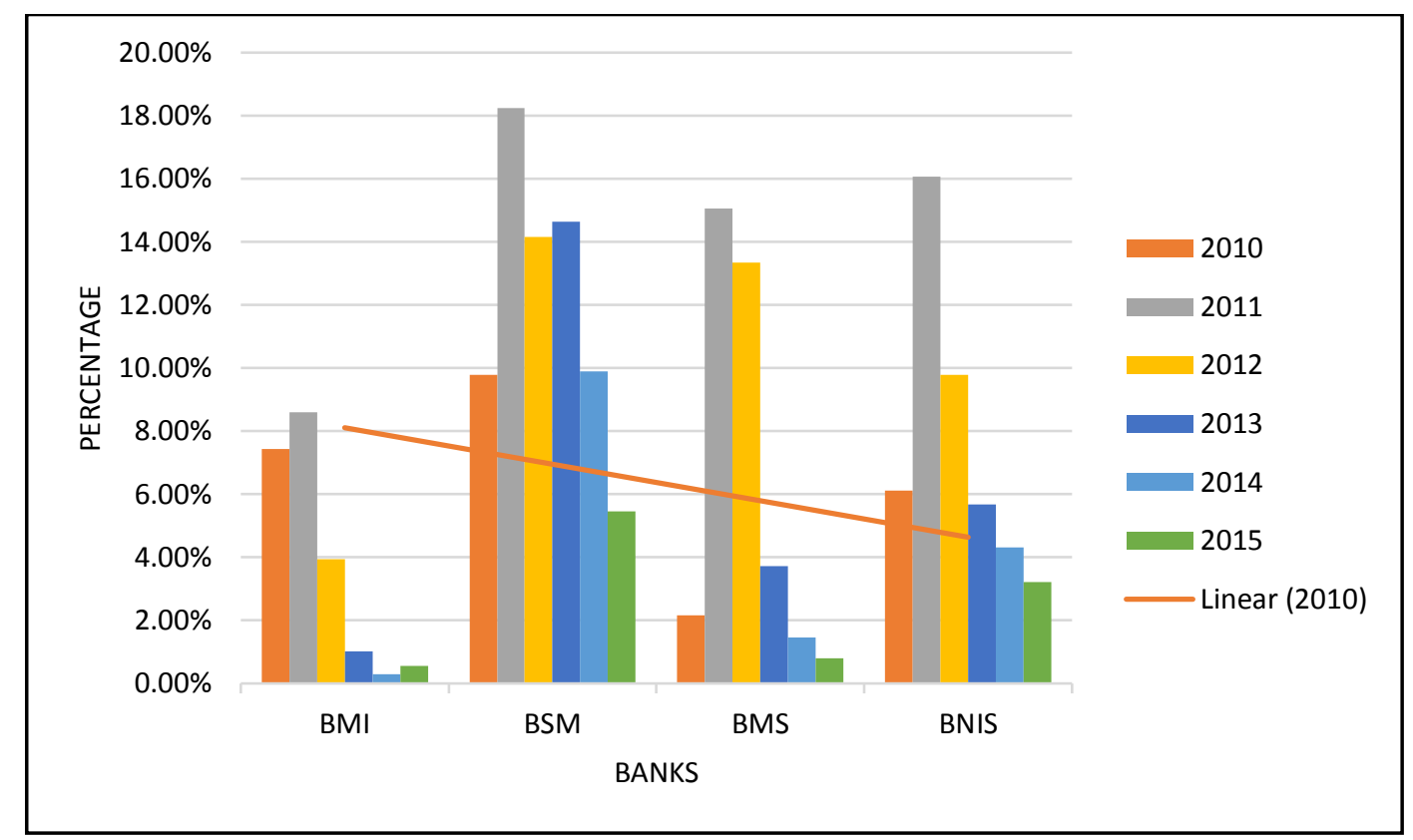

Figure 1. Trend of the ratio of qard hasan to total financing

${ }^{\mathrm{i}}$ Refer to Al-Hashr verse 7, as in https://quran.com/59/7

ii Refer to https://sustainabledevelopment.un.org/sdgs 